\title{
PROFESIONALITAS KEPALA MADRASAH DALAM PENINGKATAN MUTU PENDIDIKAN PADA MADRASAH TSANAWIYAH DDI PACONGANG PINRANG
}

\author{
Hermanto \\ Sekolah Tinggi Agama Islam (STAI) DDI Pinrang \\ Kampus: Jalan Andreas Wahani No. 27 \\ Email: hermantoddi@gmail.com
}

\begin{abstract}
Abstrak:
Penelitian ini bertujuan untuk mengetahui profesionalitas kepala madrasah dalam peningkatan mutu pendidikan pada Madrasah Tsanawiah DDI Pacongang Pinrang. Penelitian ini bersifat deskriptif kualitatif. Subyek penelitian adalah: unsur pimpinan, tenaga kependidikan, dan siswa. Metode dan instrumen penelitian yang digunakan: teknik observasi, wawancara/interview, dan angket. Teknik analisis data yang digunakan adalah analisis deskriptif kualitatif. Hasil penelitian menunjukkan bahwa faktor yang berpengaruh terhadap kualitas pendidikan di Madrasah Tsanawiyah DDI Pacongang Pinrang adalah sebagai berikut: 1) manajemen madrasah, 2) anggaran pendidikan yang memadai, 3) optimalisasi kerjasama antara pihak madrasah dengan orangtua siswa. Hambatan yang dihadapi dan solusinya dalam peningkatan kualitas pendidikan di Madrasah Tsanawiyah DDI Pacongang Pinran adalah: 1) rendahnya kualitas sarana fisik, 2) rendahnya kualitas guru, 3) rendahnya kesejahteraan guru, 4) rendahnya prestasi siswa,
\end{abstract}

\begin{abstract}
:
The purpose of this research is to know the professionality of the head master of madrasah Tsanawiah DDI Pacongang Pinrang in improving the quality of education. The subjects of research were: school leaders, education personnel, and students. Methods and research instruments used: observation, interviews, and questionnaire. The result of the research showed that the factors that influence the quality of education in Madrasah Tsanawiyah DDI Pacongang Pinrang were as follows: 1) madrasah management, 2) adequate education budget, 3) good cooperation between madrasah with parents. The obstacles faced in improving the quality of education in Madrasah Tsanawiyah DDI Pacongang Pinran were: 1) the low quality of physical facilities, 2) the low quality of teachers, 3) the low of teachers' welfare, 4) the low achievement of the students.
\end{abstract}

Kata kunci:

Pendidikan, Kepala Madrasah, Mutu Pendidikan

SALAH satu usaha yang dapat dilakukan adalah usaha peningkatan kualitas dan
mutu tenaga kependidikan sehingga mampu menjadi tenaga-tenaga yang profesional
dalam menjalankan tugas dan tanggung jawabnya sebagai tenaga pendidik termasuk
diantaranya adalah membantu siswa dengan cara menanamkan atau meningkatkan
kepercayaan diri yang tinggi. Siswa akan dapat menempuh liku-liku perjalanan hi-
dup yang penuh kesulitan sekalipun, dengan satu keyakinan bahwa suatu saat ia
akan berhasil. Dengan demikian siswa akan berani menghadapi dan dapat mengatasi 
hambatan dan kesulitan dalam belajar, baik yang bersumber dari diri sendiri maupun dari luar, sehingga akan mampu mencapai prestasi belajar secara optimal.

Dalam proses pencapaiannya, prestasi belajar sangat dipengaruhi oleh berbagai faktor. Salah satu faktor utama yang sangat berpengaruh dalam keberhasilan pembelajaran adalah keberadaan guru. Tingkat profesionalitas seorang guru harus mendapat perhatian sehingga dapat memberikan jaminan akan pencapaian tingkat prestasi belajar siswa.

Kamal Muhammad 'Isa menyatakan bahwa: "guru atau pendidik adalah pemimpin sejati, pembimbing da pengarah yang bijksana, pencetak para tokoh dan pemimpin umat". Dalam pengertian berdasarkan Undang-Undang No. 14 Tahun 2005 tentang Guru dan Dosen, sebagaimana yang tercantum dalam Bab I Ketentuan Umum pasal 1 ayat (1) dikemukakan bahwa: "Guru adalah pendidik profesional dengan tugas utama mendidik, mengajar, membimhbing, mengarahkan, melatih, menilai, dan mengevaluasi peserta didik pada pendidikan dasar dan menengah" (UU RI, 2006: 2 - 3).

Dengan demikian, sangatlah penting bagi suatu lembaga pendidikan tidak terkecuali Madrasah Tsanawiah DDI Pacongang Pinrang untuk menyusun suatu program bantuan peningkatan prestasi siswa serta tak kalah pentingnya adalah peningkatan kualitas tenaga kependidikan yang berimplikasi pada lahirnya tenaga-tenaga yang profesional pada bidangnya masing-masing.

Agar dapat menyusun program bantuan yang efektif tersebut, maka pihak madrasah memerlukan data empirik tentang profesionalitas guru dalam hubungannya dengan peningkatan prestasi belajar siswa. Penelitian ini merupakan salah satu usaha untuk memperoleh data yang dimaksud.

Berdasarkan pada uraian latar di atas, maka penulis dapat memaparkan pokok permasalahan sebagai landasan pembahasan penelitian ini: “Bagaimana Pengaruh Profesionalitas Kepala Madrasah dalam Peningkatan Mutu Pendidikan pada Madrasah Tsanawiah DDI Pacongang Pinrang".

Adapun sub-sub masalah yang dimaksud adalah sebagai berikut:

1. Bagaimana faktor-faktor yang berpengaruh terhadap peningkatan kualitas pendidikan di Madrasah Tsanawiyah DDI Pacongang Pinrang?

2. Bagaimana hambatan yang dihadapi dan solusinya dalam peningkatan kualitas pendidikan di Madrasah Tsanawiyah DDI Pacongang Pinrang?

\section{TINJAUAN PUSTAKA}

\section{Kepemimpinan Manajerial/Kepala Madrasah Tsanawiyah}

Pengembangan pemimpin atau kepala madrasah pada tingkat sekolah menengah (Madrasah Tsanawiah) pada dasamya dapat bersumber dari diri (inisiatif) sendiri sebagai pemimpin atau administrator pendidikan. Seorang kepala tidak perlu selalu menunggu saran atau perintah dari atasan, karena pada posisi ini ia memiliki kompotensi pengembangan diri melalui upaya dan daya yang tinggi dengan membaca buku-buku, majalah, koran, berkonsultasi dengan orang yang dianggap ahli pada bidangnya, atau berdiskusi dengan sesama kepala madrasah tsanawiah lainnya. 
Olehnya itu, kompotensi pemimpin juga perlu untuk mendapat perhatian dalam pengembangannya. Di sadari ataupun tidak, kondisi dunia itu adalah dinamis, yang di dalamnya selalu terjadi perubahan seiring dengan perkembangan manusia dan ilmu pengetahuan. Hal ini secara langsung akan dihadapi oleh seorang pemimpin sebagai suatu bentuk tantangan yang harus disongsong pada masa depan dengan verbagai persiapan diri, sehingga MTs DDI sebagai sasaran aktualisasi diri pemimpin dapat tetap tegak berdiri dan bahkan tetap menjadi mercu penerang dan agen pembaharuan bagi lingkungannya.

Kurangnya tindak lanjut pelatihan para kepala madrasah berimplikasi pada pola kepemimpinan yang tidak profesional, sedang seorang pimpinan pertama-tama dituntut memiliki visi, tanggungjawab, wawasan, dan keterampilan manajerial yang tangguh, peran yang dimainkannya merupakan lokomotif perubahan menuju terciptanya MTS DDI yang berkualitas.

Kemampuan mengambil inisitaif dalam melakukan perubahan paradigma berpikir dari yang lama ke paradigma berpikir yang baru sangat menunjang pencapaian visi MTS DDI Pacongang., yaitu: Madrasah yang agamis, populis, berkualitas, dan beragam. Dalam mewujudkan hal tersebut, maka Kepala Madrasah Tsanawiyah DDI Pacongang dituntut memiliki keberanian mengambil langkah baru yang meliputi beberapa hal berikut ini:

1. Membangun kepemimpinan madrasah yang kuat dengan meningkatkan koordinasi, menggerakkan semua komponen madrasah, mensinergikan semua potensi, merangsang perumusan tahapan-tahapan perwujudan visi dan misi madrasah, dan mengambif prakarsa yang berani dalam pembaharuan.

2. Menjalankan manajemen madrasah yang terbuka dalam hal pengambilan dan penggunaan keuangan madrasah. Untuk menjamin keterbukaan ini, maka manajemen madrasah hendaknya memungkinkan pengawasan dari masyarakat tanpa pihak lain.

3. Mengembangkan tim kerja yang solid, cerdas, dan dinamis. Manajemen madrasah harus berpegang pada prinsip bahwa mutu pendidikan terletak pada kolektifitas kerja. Dengan demikian, hasil pendidikan diakui sebagai hasil bersama, bukan sebagai hasil perjuangan sendiri. hal ini menuntut sikap pimpinan madrasah yang terbiasa untuk bekerja kolektif sesuai dengan fungsi masing-masing individu.

4. Mengupayakan kemandirian madrasah untuk melakukan langkah terbaik bagi madrasah. Pimpinan madrasah dituntut untuk mengandalkan kemauan, kemampuan, dan kesanggupannya sendiri tanpa menunggu petunjuk dan perintah atasan. Hal ini tentu saja dibarengi dengan upaya peningkatan sumber daya manusia, baik secara kuantitatif maupun kualitatif.

5. Menciptakan proses pembelajaran yang efektif yang dicirikan oleh beberapa hal.

a. Proses itu memberdayakan siswa untuk aktif dan partisifatif.

b. Target pembelajaran tidak terbatas pada hafalan, tetapi terkait dengan pemahaman yang ekspresif 
c. Mengutamakan intemalisasi ajaran agama dengan kesadaran sendiri.

d. Merangsang siswa untuk mempelajari berbagai cara belajar (learning how to learn).

e. Menciptakan semangat yang tinggi dalam menjalankan tugas (Made Pidarta, 1988: 117)

\section{Guru}

Menjadi seorang guru bukanlah pekerjaan yang mudah, seperti anggapan yang dibayangkan sebagian orang, dengan hanya berbekal dan bermodalkan penguasaan materi pelajaran dan menyampaikannya kepada siswa sudah dianggap cukup. Anggapan ini tentu saja sangat keliru, karena seorang guru yang professional dipersyaratkan untuk memiliki multi keterampilan, kemampuan khusus, mencintai pekerjaannya, mampu menjaga dan menjalankan kode etik guru, dan lain sebagainya.

Oemar Hamalik dalam bukunya Proses Belajar Mengajar, mempersyaratkan beberapa bentuk kemampuan yang harus dimiliki untuk menjadi guru yang profesional sebagai berikut:

1. Memiliki bakat sebagai guru

2. Memiliki keahlian sebagai guru

3. Memiliki keahlian yang baik dan terintegrasi

4. Memiliki mental yang sehat

5. Berbadan sehat

6. Memiliki pengalaman dan pengetahuan yang luas

7. Guru adalah manusia yang berjiwa Pancasila, dan

8. Guru adalah seorang warga Negara yang baik (Oemar Hamalik, 2006: 5 - 7)

Persyaratan yang demikian berat dan harus dipenuhi oleh seorang guru tentu saja sangat membutuhkan tambahan pengetahuan dan pengalaman. Tuntutan ini dapat dipenuhi dengan memberikan kesempatan dan peluang kepada masing-masing guru untuk dapat mengembangkan dirinya baik melalui pelatihan maupun kesempatan untuk melanjutkan pendidikannya pada jenjang yang lebih tinggi berdasarkan latar belakang keilmuan masing-masing guru.

Al-Ghazali menyatakan bahwa unsur penting yang tidak dapat dikesampingkan dalam profesi keguruan adalah sifat keteladanan. Menurutnya guru yang dapat diserahi tugas mengajar adalah guru yang selain cerdas dan sempurna akalnya, juga harus baik akhlaknya, dan mempunyai fisik yang kuat (Ahmad Tafsir, 2000: 113). Lebih jauh Al-Ghazali menyebutkan sifat-sifat khusus yang harus dimiliki oleh seorang guru adalah sebagai berikut:

1. Guru harus memiliki rasa kasih sayang, yang dengannya akan menimbulkan rasa percaya diri dan rasa tenteram pada peserta didik terhadap gurunya.

2. Tidak terlalu menuntut gaji atau imbalan yang tinggi atas pekerjaan guru yang ditekuninya.

3. Mampu menjadi pengarah dan penyuluh yang jujur dan benar dihadapan peserta didik.

4. Mampu menggunakan cara yang simpatik dalam menyajikan materi pelajarannya. 
5. Mampu menjadi panutan atau teladan yang baik bagi setiap peserta didiknya.

6. Mampu mengakui dengan jujur tentang adanya perbedaan potensi yang dimiliki muridnya secara individual, dan memperlakukannya sesuai dengan tingkat perbedaan yang dimilikinya itu.

7. Mampu memberikan penilaian terhadap potensi bakat, minat, serta tabiat kejiwaan dari murid-muridnya.

8. Berpegang teguh kepada prinsip yang diucapkannya, serta berupaya untuk merealisasikannya sedemikian rupa (Abuddin Nata, 2001: 96 - 98).

Delapan sifat guru yang baik sebagaimana dikemukakan di atas, tampak bahwa sebagiannya masih ada yang sejalan dengan tuntutan masyarakat modern. Sifat guru yang mengajarkan bagian berikutnya sebelum bagian terdahulu dikuasai, memahami tingkat perbedaan kejiwaan dan kemampuan intelektual para siswa, bersifat simpatik, tidak menggunakan cara-cara kekerasan, serta menjadi pribadi panutan dan teladan adalah sifat-sfat yang sejalan dengan tuntutan masyarakat modern.

Kemampuan dan profesionalitas guru diharapkan mampu menimbulkan dorongan dan rangsangan kepada siswa-siswanya, sehingga daya kreatifitas dan kemandirian siswa dalam belajar dapat dipertahankan bahkan senantiasa dapat dikembangkan secara baik.

Dalam buku yang berjudul Guru Profesional Implementasi Kurikulum Tingkat Satuan Pendidikan (KTSP) Kunandar menyebutkan bahwa; Profesionalisme berasal dari kata profesi yang artinya suatu bidang pekerjaan yang ingin atau akan ditekuni seseorang. Profesi juga diartikan sebagai suatu jabatan atau pekerjaan tertentu yang mensyaratkan pengetahuan dan keterampilan khusus yang diperoleh dari pendidikan akademis yang intensif. Jadi profesi adalah suatu pekerjaan atau jabatan yang menuntut keahlian tertentu (Kunandar, 2007: 45).

Dalam pengembangan profesionalisme kependidikan tersebut, diperlukan pemantapan kompetensi keguruan yang tergambar dalam pelaksanaan tugas sehari-hari yang bercirikan pada tiga kemampuan profesionalisme, yaitu:

1. Kepribadian guru, yang meliputi: 1) Memahami dan menghargai tiap potensi dari tiap siswa, 2) Membina situasi sosial yang meliputi interaksi belajar mengajar yang mendorong siswa dalam meningkatkan kemampuan memahami pentingnya kebersamaan dan kesepahaman arah pemikiran dan perbuatan dikalangan siswa, dan 3) Membina perasaan saling mengerti, saling menghormati dan saling bertanggung jawab dan percaya mempercayai an tara guru dan murid.

2. Penguasaan ilmu pengetahuan, dan

3. Keterampilan dalam mengajarkan bahan pelajaran. Termasuk di dalamnya adalah: Terampil dalam menggunakan dan mengembangkan alat-alat bantu bagi siswa dalam proses belajar mengajar yang diperlukan (M. Arifin, 2000: 112 - 123).

Strategi pengembangan ketenagaan ini, lebih jauh diharapkan mampu menutupi kekurangan yang ada, paling tidak ada usaha peningkatan mutu guru sehingga 
berimplikasi pada perbaikan mutu out put Madrasah Tsanawiah DDI Pacongang Pinrang.

\section{Tenaga Administrasi}

Memperhatikan kembali pada pengertian administrasi pendidikan, maka akan ditemukan beberapa bentuk pengertian yang menurut hemat penulis, semua pengertian tersebut pada hakekatnya sama. Inti yang disebutkan berkisar pada beberapa hal sebagaimana yang terdapat dalam "Dictionary of Education" administrasi pendidikan diartikan dengan:

1. Pengarahan, pengendalian dan pengelolaan semua masalah yuag berhubungan urusan persekolahan, yang meliputi administrasi keuangan, selama aspek-aspek kegiatan sekolah memang benar-benar diarahkan untuk mencapai tujuan pendidikan.

2. Pengarahan, pengendalian dan pengelolaan aspek-aspek administrasi sekolah itu terutama secara langsung diarahkan pada proses pengajaran bukan pada aspekaspek lainnya, (seperti; keuangan, guru, siswa, program pengajaran, program kerja, korikuler, metode, alat bantu mengajar dan bimbingan) (Good, 1973: 4)

Memperhatikan definisi di atas, nampaknya administrasi pendidikan itu mempunyai ruang yang sangat luas walaupun hanya dalam lingkup institusi pendidikan tingkat menengah seperti Madrasah Tsanawiyah. Walaupun demikian, perlu dikaji lebih jauh bahwa dalam administrasi pendidikan ada beberapa prinsip dasar yang harus diperhatikan. Harold Koontz dalam menganalisis pendapat yang dikemukakan oleh Frederick Taylor mengatakan bahwa:

1. Menggantikan cara yang asal-asalan dengan ilmu (pengetahuan yang tersusun).

2. Mengusahakan keharmonisan dalam gerakan kelompok, dan bukannya perpecahan.

3. Mencapai kerjasama manusia, dan bukannya individualitas yang kacau

4. Bekerja untuk out put yang semaksimal mungkin, dan bukannya out put yang terbatas, dan

5. Mengembangkan semua bawahan pada taraf yang setinggi-tingginya, sesuai dengan kemampuan yang ada pada diri dan kesejahteraan persatuan mereka sendiri (Koontz, 1984: 31)

Dengan demikian, pengembangan tenaga administrasi pendidikan sangat perlu mendapat perhatian dalam pengembangannya sama dengan tenaga-tenaga kependidikan lainnya. Ketenagaan pada bidang administrasi merupakan suatu kesatuan yang utuh dan tidak dapat dipisahkan dari ketenagaan kependidikan itu sendiri.

\section{METODE PENELITIAN}

\section{Sifat dan Jenis Penelitian.}

Penelitian ini bersifat deskriptif kualitatif, karena itu dalam penelitian ini, penulis berusaha memaparkan apa adanya dari kondisi obyek yang diteliti dengan menggunakan pendekatan analisis kualitatif. 


\section{Subyek Penelitian}

Adapun yang menjadi subyek dalam penelitian ini adalah: 1) Unsur Pimpinan, 2) Tenaga Kependidikan, baik guru, staf administrasi maupun tenaga-tenaga kepustakaan dan laboratorium dan beberapa tenaga-tenaga lainnya yang terkait, 3) Siswa-siswa pada semua tingkatan kelas.

\section{Teknik Pengumpulan Data}

Penelitian ini dimaksudkan untuk memperoleh data dan informasi mengenai obyek penelitian ini dengan cara terlibat langsung ke dalam obyek yang akan diteliti. Khusus untuk penelitian ini, metode dan instrumen penelitian yang dimaksud dapat diformulasikan sebagai berikut: Teknik Observasi, Wawancara/Interview, dan Angket.

\section{Teknik Analisis Data}

Analisis data hasil penelitian ini, lebih menekankan pada aspek kualitas dengan berusaha mengetengahkan rumusan-rumusan teoritik yang dinilai refresentatif dan sesuai dengan kebutuhan penelitian. Teknik analisis data yang digunakan adalah analisis deskriptif kualitatif.

\section{HASIL DAN PEMBAHASAN}

\section{Identifikasi Faktor yang Berpengaruh terhadap Peningkatan Kualitas Pendidikan di Madrasah Tsanawiyah DDI Pacongang Pinrang}

Adapun faktor yang berpengaruh terhadap kualitas pendidikan di Madrasah Tsanawiyah DDI Pacongang Pinrang adalah sebagai berikut:

\section{Manajemen Madrasah}

Kepala madrasah sebagai manajer dalam sebuah madrasah, tentu mempunyai pola dan kemampuan untuk meningkatkan kualitas pendidikan di lembaga yang dipimpinnya.

Kemampuan manajemen Kepala Madrasah Tsanawiyah DDI Pacongang Pinrang dalam meningkatkan kualitas pendidikan di Madrasah Tsanawiyah DDI Pacongang Pinrang dapat dilihat melalui kemampuannya dalam menjalankan fungsifungsi manajemen berdasarkan kuesioner terhadap 24 orang guru Madrasah Tsanawiyah DDI Pacongang Pinrang, dapat dilihat dalam tabel sebagai berikut:

\section{Tabel 11}

Kemampuan Manajemen Kepala Madrasah dalam Meningkatkan Kualitas Pendidikan Di Madrasah Tsanawiyah

DDI Pacongang Pinrang

\begin{tabular}{|c|c|c|c|c|c|c|c|}
\hline \multirow{2}{*}{$\begin{array}{c}\text { No } \\
\cdot\end{array}$} & $\begin{array}{c}\text { Kemampuan } \\
\text { Manajemen } \\
\text { Kepala Madrasah }\end{array}$ & \multicolumn{2}{|c|}{$\begin{array}{c}\text { Skala } \\
\text { Pengukuran }\end{array}$} & \multirow{2}{*}{$\begin{array}{c}\text { Y } \\
\mathbf{m}\end{array}$} & \multicolumn{2}{|c|}{$\begin{array}{c}\text { Persentase } \\
\mathbf{( \% )}\end{array}$} & $\begin{array}{c}\text { Total } \\
\mathbf{( \% )}\end{array}$ \\
\hline \hline 1 & Perencanaan & 20 & 4 & 24 & 83,33 & 16,67 & 100 \\
\hline
\end{tabular}




\begin{tabular}{|c|l|c|c|c|c|c|c|}
\hline 2 & Pengorganisasian & 18 & 6 & 24 & 75,00 & 25,00 & 100 \\
\hline 3 & Bimbingan & 20 & 4 & 24 & 83,33 & 16,67 & 100 \\
\hline 4 & Koordinasi & 19 & 5 & 24 & 79,17 & 20,83 & \\
\hline \hline & Jumlah & & & & $\mathbf{8 0 , 2 1}$ & $\mathbf{1 9 , 7 9}$ & $\mathbf{1 0 0}$ \\
\hline
\end{tabular}

\section{Sumber data : Hasil pengolahan data angket, 2013}

Dari pengolahan data di atas dapat dijelaskan bahwa kemampuan manajemen Kepala Madrasah Tsanawiyah DDI Pacongang Pinrang untuk perencanaan, sebanyak 20 orang atau 83,33 persen yang menyatakan bahwa kepala madrasah mampu membuat perencanaan dengan baik. Sementara hanya 4 orang responden atau 16,67 persen yang menyatakan bahwa kepala madrasah tidak memiliki kemampuan membuat perencanaan.

Untuk kemampuan pengorganisasian, sebanyak 18 responden atau 75,00 persen yang menyatakan bahwa Kepala Madrasah Tsanawiyah DDI Pacongang Pinrang, sedangkan 6 orang atau 25,00 persen yang menilai bahwa kepala madrasah tidak memiliki kemampuan pengorganisasian yang baik.

Sebanyak 20 responden atau 83,33 persen yang menganggap bahwa Kepala Madrasah Tsanawiyah DDI Pacongang Pinrang memiliki kemampuan memberikan bimbingan kepada staf dan bawahannya. Sementara 4 responden atau 16,67 yang menyatakan bahwa kepala madrasah tidak mampu memberikan bimbingan kepada bawahannya.

Kemampuan Kepala Madrasah Tsanawiyah DDI Pacongang Pinrang dalam melakukan koordinasi dinilai oleh 19 responden atau 79,17 persen, sedangkan 5 responden atau 20,83 persen yang menyatakan bahwa kepala madrasah tidak mampu melakukan koordinasi dengan baik.

Berdasarkan pengolahan data di atas, menunjukkan bahwa kemampuan manajemen Kepala Madrasah Tsanawiyah DDI Pacongang Pinrang mendapat nilai rata-rata sebanyak 80,21 persen yang menyatakan bahwa kepala madrasah memiliki kemampuan manajemen yang baik. Sedangkan 19,79 persen menyatakan bahwa kepala madrasah tidak memiliki kemampuan manajemen.

Kemampuan manajemen Kepala Madrasah Tsanawiyah DDI Pacongang Pinrang dapat ditetapkan berdasarkan skala interval tiga, yaitu tinggi, sedang/cukup, dan rendah/kurang. Diketahui bahwa jarak pengukuran tertinggi adalah 83,33 persen dan jarak pengukuran terendah adalah adalah 16,67 persen, sedangkan jumlah interval ditetapkan sebanyak 3, yaitu tinggi/baik, sedang/cukup, dan rendah/kurang. Pada hasil pengolahan data ditemukan bahwa tingkat kemampuan manajemen Kepala Madrasah Tsanawiyah DDI Pacongang Pinrang adalah tinggi.

Kemampuan manajemen Kepala Madrasah Tsanawiyah DDI Pacongang Pinrang dalam membuat perencanaan, sebagaimana dikemukakan oleh salah seorang guru bahwa setiap ingin melakukan suatu kegiatan, selalu didahului dengan pembuatan perencanaan. Setiap tahun ajaran baru, diadakan rapat kerja untuk menyusun 
program kerja satu tahun pelajaran ke depan. Demikian pula hal-hal lain yang dianggap penting (Aswar, wawancara, 10 Maret 2013).

Demikian pula diungkapkan oleh Asrim, salah seoran guru Madrasah Tsanawiyah DDI Pacongang Pinrang bahwa sebelum melakukan kegiatan, Kepala Madrasah selalu membuat perencanaan yang disampaikan kepada seluruh komponen melalui rapat atau pengumuman (Hajirana, Guru, wawancara, 10 Maret 2013).

Sebagai manajer, kepala madrasah memang dituntut untuk membuat perencanaan baik jangka pendek, jangka menengah dan jangka panjang dalam rangka peningkatan kualitas pendidikan di Madrasah Tsanawiyah DDI Pacongang Pinrang.

Demikian pula Kepala Madrasah Tsanawiyah DDI Pacongang Pinrang sebagai pemimpin dalam organisasi, ia mampu menjalankan tugasnya dengan baik. Hal tersebut berdasarkan hasil wawancara dengan salah seorang guru Madrasah Tsanawiyah DDI Pacongang Pinrang bahwa salah satu kemampuan Kepala Madrasah Tsanawiyah DDI Pacongang Pinrang adalah pengorganisasian. Seperti membagi tugas kepada guru-guru berdasarkan keahlian masing-masing, misalnya menjadi pembina Pramuka, pembina unit kesehatan sekolah (UKS) dan sebagainya (Muh. Tahir, Guru, wawancara, 10 Maret 2013).

Dalam memberikan bimbingan, Kepala Madrasah Tsanawiyah DDI Pacongang Pinrang senantiasa memberikan teladan yang baik. Menurut hasil wawancara dengan Kepala Tata Usaha Madrasah Tsanawiyah DDI Pacongang Pinrang bahwa kepala madrasah selalu memberikan teladan yang baik. Contohnya beliau selalu datang lebih awal dari staf dan bawahannya serta para siswa. Demikian pula biasanya pulang setelah staf dan bawahannya sudah kembali (Muh. Syarif, KTU, wawancara, 10 Maret 2013).

Demikian pula yang disampaikan oleh Salma Abdullah, bahwa kepala madrasah senantiasa memberikan bimbingan yang baik terhadap staf, bawahan dan para siswanya. Salah satu bimbingan yang biasa dilakukan adalah memberikan bimbingan kepada guru yang diberi tugas tertentu, atau memberikan koreksi kepada guru yang melakukan kekeliruan dan sebagainya (Nelly Idrus, Guru, wawancara, 10 Maret 2013).

Kepala Madrasah sebagai pimpinan dalam sebuah madrasah memang harus memberikan contoh dan teladan yang baik (uswah hasanah) terhadap bawahannya, sehingga dapat ditaati dan berwibawa. Dengan demikian, terjalin suasana hubungan antara atasan dan bawahan dengan tetap terjaganya hubungan silaturrahim yang baik di antara seluruh komponen Madrasah Tsanawiyah DDI Pacongang Pinrang.

\section{Anggaran Pendidikan yang Memadai}

Anggaran pendidikan yang memadai merupakan faktor yang mempengaruhi peningkatan kualitas pendidikan di Madrasah Tsanawiyah DDI Pacongang Pinrang. Karena anggaran yang memadai merupakan sumber daya lembaga pendidikan yang ikut menentukan pencapaian tujuan lembaga pendidikan.

Sebagaimana diungkapkan Bendahara Madrasah Tsanawiyah DDI Pacongang Pinrang bahwa anggaran belanja dari Anggaran Pendapatan dan Belanja Negara (APBN) untuk Madrasah Tsanawiyah DDI Pacongang Pinrang masih sangat terbatas. 
Hampir seluruhnya dialokasikan untuk belanja pegawai, yaitu gaji pegawai negeri sipil dan tenaga honorer/sosial (Muammar H., Bendahara, wawancara, Tanggal $20 \mathrm{Ma}-$ ret 2012).

Hasil wawancara dengan Kepala Tata Usaha Madrasah Tsanawiyah DDI Pacongang Pinrang disebutkan bahwa perbandingan antara tenaga pendidik dan kependidikan yang berstatus pegawai negeri sipil (PNS) dengan non-PNS atau honorer/sosial adalah 10:16 dengan persentase 38 persen tenaga pendidik dan kependidikan yang berstatus PNS sementara yang non-PNS sebanyak 62 persen (Muh. Syarif, KTU, wawancara, Tanggal 2 Maret 2012).

Keadaan yang demikian, tentu saja sebuah hal yang terkesan mengherankan melihat statusnya yang masuk kategori negeri. Sementara tenaga pendidik dan kependidikannya lebih banyak berstatus non-PNS.

\section{Optimalisasi Kerjasama antara Pihak Madrasah dengan Orangtua Siswa.}

Kerjasama antara pihak madrasah dengan orangtua siswa merupakan salah satu faktor yang mempengaruhi kualitas pendidikan di Madrasah Tsanawiyah DDI Pacongang Pinrang. Dengan kerjasama tersebut, madrasah dapat berkembang lebih baik. Peran orangtua siswa di madrasah diwadahi oleh Komite Madrasah, yang bertujuan untuk membantu kelancaran penyelenggaraan pendidikan di madrasah. Dengan pemikiran bersama antara pihak sekolah dan wali murid, diharapkan masalah-masalah yang selama ini dapat diatasi dengan baik.

Melalui wadah Komite Madrasah, dicapai kesepatakan bersama untuk mengembangkan sarana dan prasarana, baik pembangunan gedung sekolah yang menjadi pokok permasalahan dari tahun ke tahun.

Hal ini dipertegas oleh salah seorang Pengurus Komite Sekolah bahwa dengan kerjasama yang baik dengan pihak pengelola Madrasah Tsanawiyah DDI Pacongang Pinrang, maka dapat dilakukan beberapa hal yang dapat memungkinkan pengembangan madrasah ke arah yang lebih di antaranya adalah mengadakan pertemuan yang berkala untuk membahas persoalan yang muncul, berpartisipasi dalam kegiatan khususnya har-hari besar agama Islam, serta berupaya mengadakan kerjasama dengan pengusaha dan pejabat (Jafar Sanusi, Komite, wawancara, Tanggal 2 Maret 2012).

Namun demikian, menurut Kepala Madrasah Tsanawiyah DDI Pacongang Pinrang peran orangtua siswa terutama dalam membantu pengadaan anggaran pendidikan tidak terlalu bisa diharapkan. Sebagian besar orangtua siswa di Madrasah Tsanawiyah DDI Pacongang Pinrang adalah berpenghasilan ekonomi menengah ke bawah. Bahkan di antara siswa sekitar 30 orang berasal dari panti asuhan di kota Parepare. Sehingga untuk pembayaran uang komite madrasah, mereka dibebaskan (Abdul Rachim, Kepala Madrasah, wawancara, tanggal 09 Maret 2013).

Dengan demikian, dapat disimpulkan bahwa kerjasama antara pihak madrasah dengan pihak orangtua siswa belum optimal. Kerjasama yang berlangsung masih terbatas pada menghadiri rapat yang diadakan, menghadiri acara hari besar agama Islam. Sementara peran yang lebih besar sebagai mitra pihak madrasah yang diharapkan untuk mengembangkan madrasah ke arah yang lebih maju, masih sangat kurang. Peran itu hanya sebatas membayar uang komite madrasah setiap bulan. 


\section{Identifikasi Hambatan yang Dihadapi dan Solusinya dalam Peningkatan Kualitas Pendidikan di Madrasah Tsanawiyah DDI Pacongang Pinrang}

Ada beberapa masalah atau hambatan yang dihadapi oleh Madrasah Tsanawiyah DDI Pacongang Pinrang dalam upaya peningkatan kualitas pendidikan khususnya yang berkaitan dengan penyelenggaraan pendidikan. Di antara masalah tersebut adalah sebagai berikut:

\section{Rendahnya Kualitas Sarana Fisik}

Upaya pengembangan madrasah adalah dengan mengembangkan pembangunan sarana dan prasarana yang dibutuhkan dalam rangka peningkatan kualitas pendidikan di Madrasah Tsanawiyah DDI Pacongang Pinrang. Adapun fasilitas sarana dan prasarana yang sudah ada di Madrasah Tsanawiyah DDI Pacongang Pinrang dapat dijelaskan pada pembahasan selanjutnya.

Ruang kelas sebanyak 6 (enam) buah, yang digunakan sebagai sarana pembelajaran. Gedung sekolah yang dipakai sampai sekarang ini adalah gedung sejak berdirinya pada tahun 1987, kecuali ada tiga lokal gedung tambahan yang dibangun pada tahun 1996.

Berdasarkan observasi ruang kelas yang dipergunakan kurang layak. Papan tulis yang dipakai masih papan tulis yang memakai kapur sebagai alat tulis, belum menggunakan white board. Demikian pula belum menggunakan media/alat pembelajaran seperti UHP dan LCD. Lantai ruangan kelas yang sudah banyak rusak. Kesimpulannya, gedung dan ruangan belajar perlu direnovasi agar suasana pembelajaran lebih nyaman dan kondusif.

Solusi yang ditempuh untuk mengatasi hambatan tersebut di atas, secara bertahap pihak madrasah merenovasi gedung, khususnya lantai ruang kelas yang berjumlah tiga yang sudah mulai rusak. Demikian pula penggunaan white board, direncanakan dilengkapi pada tahun ajaran baru 2013 - 2010.

Berdasarkan hasil wawancara dengan Kepala Madrasah Tsanawiyah DDI Pacongang Pinrang bahwa renovasi gedung dan pengadaan kelengkapan masing-masing kelas dilaksanakan secara bertahap. Hal ini disebabkan karena belum adanya dana khusus renovasi dari pemerintah (Abdul Rachim, Kepala Madrasah Tsanawiyah DDI Pacongang Pinrang, wawancara, Pinrang, tanggal 09 Maret 2013 (Abdul Rachim, Kepala Madrasah, wawancara, tanggal 09 Maret 2013).

Laboratorium IPA yang digunakan siswa untuk praktikum. Laboratorium ini kondisinya sudah kurang layak pakai, baik gedung maupun alat peraganya. Perpustakaan, yang dipergunakan siswa dan guru untuk referensi, kondisinya juga memprihatinkan. Koleksi bukunya masih kurang memadai, dan masih banyak buku kurikulum lama yang tersimpan. Letak gedungnya juga tidak strategis, karena berhadapan langsung dengan sinar matahari.

Berdasarkan hasil wawancara dengan Kepala Madrasah Tsanawiyah DDI Pacongang Pinrang bahwa untuk mengatasi masalah yang berkaitan dengan laboratorium IPA dan perpustakaan yang belum berfungsi sebagaimana mestinya, pihak madrasah 
menempuh beberapa langkah antara lain: Setiap tahun anggaran berjalan dialokasikan pengadaan alat peraga, sementara untuk menambah koleksi buku perpustakaan, setiap siswa yang tamat diwajibkan menyumbang buku atau uang yang dipergunakan untuk membeli koleksi buku (Hj. Nurbaya, Wakil Kepala Madrasah, wawancara, 09 Maret 2013).

Menurut Kepala Madrasah Tsanawiyah DDI Pacongang Pinrang bahwa hambatan yang dihadapi dalam penggunaan mushalla sebagai sarana ibadah adalah disebabkan karena air PDAM tidak sampai ke lokasi mushalla. Sehingga mushalla tidak dapat digunakan oleh siswa atau guru untuk melaksanakan shalat, khususnya shalat Dzuhur berjamaah (Abdul Rachim, Kepala Madrasah, wawancara, tanggal 09 Maret 2013).

Sarana dan prasarana yang sama sekali belum tersedia adalah laboratorium komputer dan bahasa, aula madrasah serta lokasi madrasah yang belum dipagari, sehingga mengakibatkan siswa dengan mudah bolos atau keluar dengan seenaknya dari lokasi madrasah pada saat proses pembelajaran masih berlangsung.

Menyadari hal tersebut, pimpinan yang dalam hal ini kepala madrasah beserta wakilnya dan didukung oleh Komite Madrasah Tsanawiyah DDI Pacongang Pinrang berusaha melengkapi serta memenuhi kebutuhan pendidikan menyangkut sarana dan prasarana, antara lain:

1. Mengadakan laboratorium komputer.

2. Mengadakan fasilitas laboratorium bahasa.

3. Menambah fasilitas perpustakan dengan ruang bacaan dengan area yang memadai sehingga siswa merasa nyaman untuk membaca, diskusi dan belajar lainnya.

4. Fasilitas OSIS dengan ruang khusus.

5. Fasilitas ruang UKS dengan beberapa tempat tidur/dipan untuk perlengkapan apabila ada siswa perlu perawatan kesehatan khusus (Hj. Nurbaya, Wakil Kepala Madrasah, wawancara, 09 Maret2013).

Sarana tersebut merupakan kebutuhan yang sangat penting untuk meningkatkan kualitas pendidikan di Madrasah Tsanawiyah DDI Pacongang Pinrang. Laboratorium komputer dan laboratorium bahasa adalah sumber belajar yang sangat dibutuhkan untuk keterampilan (life skills) siswa untuk menghadapi persaingan di era kompetisi yang membutuhkan kemampuan penguasaan di bidang ilmu pengetahuan dan teknologi.

Untuk praktikum komputer untuk mata pelajaran Teknologi Informasi dan Komunikasi (TIK) solusi sementara adalah praktikum siswa menggunakan komputer yang ada di kantor. Menurut guru TIK bahwa dirinya membuat jadwal praktikum dengan 3 orang siswa sekali praktik, sesuai dengan jumlah komputer yang ada di kantor madrasah. Praktikum yang diberikan juga masih terbatas pengoperasian dasar komputer seperti turn on dan turn off komputer dan menggunakan microsoft word dan microsoft excel. Hal ini disebabkan karena pengetahuan siswa yang masih terbatas dan kurangnya komputer yang tersedia (Muammar, H., Guru, wawancara, Tanggal 20 Maret 2012). 
Tersedianya sarana dan prasarana merupakan hal yang sangat penting dalam peningkatan kualitas pendidikan di Madrasah Tsanawiyah DDI Pacongang Pinrang.

\section{Rendahnya Kualitas Guru}

Salah satu masalah yang dihadapi dalam peningkatan kualitas pendidikan di Madrasah Tsanawiyah DDI Pacongang Pinrang adalah masih rendahnya kualitas guru. Rendahnya kualitas guru dalam proses pembelajaran adalah masih adanya guru mengajar tidaksesuai dengan kualifikasi pendidikannya. Untuk lebih jelasnya dapat dilihat melalui tabel berikut ini:

\section{Tabel 19}

Kondisi Guru dilihat dari Disiplin Ilmu Yang Ditekuni

\begin{tabular}{|c|l|c|c|}
\hline No & \multicolumn{1}{|c|}{ N a m a } & $\begin{array}{c}\text { Latar } \\
\text { Belakang } \\
\text { Pendidikan }\end{array}$ & $\begin{array}{c}\text { Mata Pelajaran } \\
\text { yang Diajarkan }\end{array}$ \\
\hline 1 & Abdul Rachim, S. Pd.I & S1 PAI & B. Arab \\
\hline 2 & Dra.Hj. Nurbaya & S1 PAI & IPS \\
\hline 3 & Musdalifah, S. Ag & S1 PAI & Qur'an Hadis \\
\hline 4 & Najmiah, S. Pd.I & S1 PAI & Pkn \\
\hline 5 & Zainuddin L, S. Ag & S1 PAI & Kespro \\
\hline 6 & Drs. Muh. Tahir & S1 PAI & Penjaskes \\
\hline 7 & Hermanto, S. Ag & S1 PAI & B. Indonesia \\
\hline 8 & Asma A, S. Pd. I & S1 PAI & SKI \\
\hline 9 & Muammar H, S. Pd.I & S1 PAI & TIK \\
\hline 10 & Dra. Hajirana & S1 Pkn & Biologi \\
\hline 11 & Drs. Muh. Yunus & S1 & Matematika \\
\hline 12 & Ummi Hayati, S. Ag & S1 PAI & Q. Hadis, Fiqhi \\
\hline 13 & Nelly Idrus, S. Pd.I & S1 PAI & B. Daerah \\
\hline 14 & Nurhaeda, S. Pd & S1 PAI & Fisika \\
\hline 15 & Anwar & MAN & Ke DDI an \\
\hline 16 & Fitriani, S. Pd. I & S1 PAI & Peng. Diri \\
\hline 17 & Agussalim & Matematika \\
\hline 18 & Muliani & B. Inggeris \\
\hline
\end{tabular}

Sumber: Dokumen Madrasah Tsanawiyah DDI Pacongang Pinrang tahun pelajaran 2012/2013

Dari data di atas, sebanyak 8 orang guru atau 31 persen, guru mengajarkan mata pelajaran tidak sesuai dengan latar belakang pendidikannya. Sementara sebanyak 
18 orang guru atau 68 persen guru mengajarkan mata pelajaran sesuai dengan latar belakang pendidikannya.

Di antara mata pelajaran yang diajarkan oleh guru yang tidak sesuai dengan latar belakang pendidikannya adalah mata pelajaran TIK yang diajarkan oleh guru dengan latar belakang pendidikan Bahasa Inggris dan Teknik Sipil. Guru Matematika mengajarkan mata pelajaran Sejarah, Guru Pendidikan Agama Islam mengajarkan Sosiologi dan mata pelajaran Seni Budaya diajarkan oleh guru yang berlatarbelakang pendidikan Bahasa Inggris.

Solusi untuk mengatasi masalah tersebut dijelaskan oleh Wakil Kepala Madrasah Tsanawiyah DDI Pacongang Pinrang bagian Kurikulum bahwa memang sebuah dilema kalau semua mata pelajaran dituntut untuk diajarkan sesuai dengan latar belakang pendidikannya. Karena guru yang sesuai dengan mata pelajaran tersebut memang tidak ada di Madrasah Tsanawiyah DDI Pacongang Pinrang. Untuk mengatasi terbatasnya guru yang sesuai dengan latar belakang pendidikannya, maka guru tersebut diikutkan dalam setiap pelatihan atau bimbingan baik yang diadakan oleh Dinas Pendidikan atau Departemen Agama Kota Parepare. Begitupula di tingkat Provinsi yang diadakan setiap tahun. Dengan hal ini, diharapkan kemampuan guru dalam mengajarkan mata pelajaran semakin meningkat dengan baik (Hj. Nurbaya, Wakil Kepala Madrasah, wawancara, Tanggal 20 Maret 2012).

Berdasarkan pada tabel tersebut di atas, berarti secara seimbang pembinaan guru mata pelajaran dapat dilakukan secara baik dalam memantapkan pemahaman terhadap disiplin ilmu keahliannya, baik melalui koordinasi dan komunikasi sesama guru mata pelajaran maupun dengan berbagai kegiatan pendidikan dan pelatihan tentang disiplin ilmu tersebut.

Demikian pula, para guru mata pelajaran diberikan kesempatan yang seluas-luasnya oleh Kepala Madrasah untuk melanjutkan pendidikannya ke jenjang lebih tinggi, khususnya S2. Hal ini ditempuh, agar kualitas sumber daya manusia guru di Madrasah Tsanawiyah DDI Pacongang Pinrang dapat meningkat.

Hal ini diakui oleh salah seorang guru yang sementara melanjutkan pendidikannya di jenjang S2 bahwa selama dalam kepemimpinan Kepala Madrasah Tsanawiyah DDI Pacongang Pinrang sekarang guru diberikan kesempatan yang seluas-luasnya untuk mengikuti pendidikan S2, dengan pertimbangan untuk peningkatan kualitas sumber daya manusia. Namun, sampai sekarang belum ada seorang guru pun yang melanjutkan pendididkannya di strata dua (S2). Padahal, hal tersebut diharapkan selain untuk peningkatan kualitas sumber daya manusia guru itu sendiri, juga untuk meningkatkan nilai jual/promosi Madrasah Tsanawiyah DDI Pacongang Pinrang (Hj. Nurbaya, Guru, wawancara, 10 Maret 2013).

\section{Rendahnya Kesejahteraan Guru}

Rendahnya kesejahteraan guru merupakan salah satu hambatan dalam peningkatan kualitas pendidikan di Madrasah Tsanawiyah DDI Pacongang Pinrang. Hal ini disebabkan karena masih minimnya gaji yang diterima oleh guru. Walaupun anggaran pendidikan di APBN sudah mencapai $20 \%$. Tapi belum terlalu memberikan pe- 
ngaruh positif terhadap peningkatan kesejahteraan gaji. Maka, di antara guru masih ada yang mencari pekerjaan sambilan selain menjadi guru.

Menurut Kepala Madrasah Tsanawiyah DDI Pacongang Pinrang bahwa pekerjaan sambilan guru Madrasah Tsanawiyah DDI Pacongang Pinrang di antaranya adalah penjual bahan pakaian bekas yang marak di Parepare. Ada juga yang masuk dalam produk yang berbasis multi level marketing (MLM). Pekerjaan ini pada dasarnya tidak mempengaruhi dalam mengajar. Tetapi hal ini merupakan bentuk masih minimnya kesejahteraan guru. Walaupun nilai kepuasan itu sebenarnya tergantung kepada diri kita sendiri (Abdul Rachim, Kepala Madrasah, wawancara, 09 Maret2013).

Salah satu bentuk peningkatan kesejahteraan guru adalah bagi guru yang telah lulus sertifikasi, diberikan tambahan penghasilan satu kali lipat dari gaji pokok. Tapi sampai saat ini, sudah ada dua orang guru yang telah lulus sertifikasi sejak Oktober 2007, tapi belum menerima tunjangan tersebut.

Menurut salah seorang guru Madrasah Tsanawiyah DDI Pacongang Pinrang yang lulus sertifikasi bahwa seharusnya dirinya sudah menerima tunjangan sertifikasi sejak Oktober 2008. Tapi sampai saat ini, belum ada realisasinya (Muh. Yunus, Guru, wawancara, 10 Maret2013).

Hal senada juga disampaikan oleh Muhammad Rivai bahwa dirinya juga sudah lulus sertifikasi sejak Oktober 2007, tapi belum menerima tunjangan seperti yang dijanjikan oleh pemerintah. Sekedar perbandingan bahwa guru yang berada di bawah naungan Dinas Pendidikan Kota Parepare (Departemen Pendidikan Nasional) sudah banyak yang menerima tunjangan tersebut. Tapi ia dan temannya yang lain yang berada di bawah naungan Departemen Agama belum menerimanya (Muhammad Tahir, Guru, wawancara, 10 Maret 2013).

Sertifikasi memang menjadi angin segar bagi tenaga pendidik/guru. Dengan sertifikasi, guru menerima berbagai macam tunjangan yang bertujuan untuk meningkatkan kesejahteraan guru. Tapi, kalau sampai saat ini belum menerima tunjangan tersebut, menurut peneliti ada dua kemungkinannya, yaitu anggarannya belum cair atau masih ada persyaratan untuk menerima tunjangan tersebut belum dipenuhi oleh guru tersebut.

Lebih-lebih bagi guru yang masih berstatus sebagai guru sosial/ honorer. Kesejahteraannya masih jauh dari harapan. Sebagaimana dijelaskan di atas bahwa guru honorer di Madrasah Tsanawiyah DDI Pacongang Pinrang lebih banyak dibanding guru PNS. Dari 26 orang guru Madrasah Tsanawiyah DDI Pacongang Pinrang, 16 orang atau 62 persen masih berstatus honorer. Sementara 10 orang atau 38 persen yang berstatus pegawai negeri sipil (PNS).

Menurut salah seorang guru honorer menyatakan bahwa ia sudah mengabdi selama 15 tahun, tapi sampai saat ini belum juga terangkat menjadi pegawai negeri sipil (PNS). Sebenarnya ia sudah lulus CPNS hasil dari pendataan Departemen Agama tahun 2006, tapi sampai saat ini ia belum menerima surat keputusannya (Zainuddin, Guru, wawancara, 10 Maret 2013). 
Seorang guru honorer lainnya juga menyatakan bahwa ia mengajar sebagai guru honorer untuk mengabdikan dirinya atau mengamalkan ilmunya, sambil berharap agar suatu saat ia juga bisa diangkat menjadi pegawai negeri sipil (PNS) (Musdalifah, Guru, wawancara, 10 Maret 2013).

Guru honorer di Madrasah Tsanawiyah DDI Pacongang Pinrang mendapatkan insentif dari anggaran rutin setiap bulan. Selain itu, ada tunjangan fungsional guru honorer yang berasal dari anggaran pendapatan dan belanja negara (APBN) yang disalurkan melalui Departemen Agama Republik Indonesia. Walaupun ini masih sangat minim, tetapi setidaknya sudah ada kepedulian pemerintah kepada guru honorer/sosial.

Untuk meningkatkan kesejahteraan guru tersebut, solusinya lebih banyak dibebankan kepada pemerintah. Pemerintah diharapkan dapat merealisasikan tunjangan bagi guru yang lulus sertifikasi. Dan bagi guru honorer/sosial tunjangan fungsionalnya lebih ditingkatkan lagi yang sekarang ini berjumlah dua ratus ribu per bulan.

Pihak Madrasah Tsanawiyah DDI Pacongang Pinrang juga tidak bisa berbuat banyak untuk meningkatkan kesejahteraan guru baik PNS maupun non PNS. Hal ini disebabkan karena belum menerima dana bantuan operasional sekolah (BOS) dan dana pendidikan gratis yang diberikan oleh Pemerintah Provinsi Sulawesi Selatan. Karena kedua bantuan tersebut hanya diberikan kepada sekolah dasar/madrasah ibtidaiyah atau yang sederajat serta sekolah menengah pertama/madrasah tsanawiyah atau yang sederajat.

Sementara bantuan dari masyarakat, khususnya dari orangtua siswa melalui Komite Madrasah tidak bisa diharapkan. Karena rata-rata mereka berpenghasilan ekonomi menengah ke bawah bahkan beberapa di antara mereka berasal dari panti asuhan di sekitar madrasah (Abdul Rachim, Kepala Madrasah, wawancara, Pinrang, 09 Maret 2013).

Masalah kesejahteraan guru ini memang harus segera diatasi dan dicari solusinya. Karena tidak dipungkiri bahwa peningkatan kualitas pendidikan di Madrasah Tsanawiyah DDI Pacongang Pinrang tidak lepas dari peningkatan atau terjaminnya kesejahteraan guru.

\section{Rendahnya Prestasi Siswa}

Untuk menentukan prestasi siswa diperlukan tindakan evaluasi. Evaluasi merupakan suatu tindakan untuk menentukan nilai sesuatu. Sebagai alat penilaian hasil pencapaian tujuan pembelajaran, evaluasi harus dilakukan secara terus menerus. Evaluasi tidak hanya sekedar menentukan angka keberhasilan belajar, tetapi yang lebih penting adalah sebagai dasar untuk umpan balik dari proses interaksi pembelajaran yang dilaksanakan.

Hasil interaksi proses pembelajaran yang dicapai oleh siswa mencerminkan prestasi akademik dan sekaligus menunjukkan keberhasilan guru dalam mengelola proses pembelajaran tersebut. Pengukuran prestasi siswa dari hasil pembelajaran didasarkan pada penilaian hasil belajar tersebut yang dapat diperoleh dari buku legger nilai evaluasi siswa. 
Komponen hasil penilaian siswa dinyatakan dalam skor yang diperoleh dari nilai rata-rata masing-masing mata pelajaran. Dari masing-masing prestasi akademik siswa dijumlahkan untuk mengetahui mean, median dan modus, sehingga obyektivitas, validitas dan reliabilitas data hasil penelitian dapat dipertanggungjawabkan.

Nilai prestasi akademik siswa pada Madrasah Tsanawiyah DDI Pacongang Pinrang dapat dikategorikan cukup. Nilai tersebut menunjukkan bahwa prestasi akademik siswa Madrasah Tsanawiyah DDI Pacongang Pinrang masih rendah. Karena tak satupun mata pelajaran yang mendapatkan kategori nilai rata-rata 8 (baik), 9 (amat baik) dan 10 (istimewa).

Demikian pula prestasi akademik siswa Madrasah Tsanawiyah DDI Pacongang Pinrang yang mengikuti ujian nasional. Berdasarkan hasil dokumentasi dalam dua terakhir (tahun pelajaran 2006/2007 dan 2012/2013) prestasi siswa menurun. Indikatornya adalah pada tahun pelajaran 2006/2007 $15 \%$ siswa atau 11 orang dari 67 orang siswa dinyatakan tidak lulus ujian nasional. Demikian pula pada tahun pelajaran 2012/2013 dari 78 siswa yang ikut ujian nasional, $20 \%$ atau 15 orang siswa dinyatakan tidak lulus ujian nasional.

Rendahnya prestasi akademik Madrasah Tsanawiyah DDI Pacongang Pinrang merupakan salah satu hambatan dalam peningkatan kualitas pendidikan. Menurut observasi penulis, rendahnya prestasi akademik siswa Madrasah Tsanawiyah DDI Pacongang Pinrang disebabkan beberapa faktor antara lain adalah kurangnya maksimalnya program pengajaran yang dilakukan oleh guru, pengembangan sumber belajar yang masih kurang serta minat siswa itu sendiri dalam belajar.

Menurut hasil wawancara dengan Wakil Kepala Madrasah Tsanawiyah DDI Pacongang Pinrang bahwa rendahnya prestasi siswa terutama disebabkan masih adanya guru yang melakukan proses pembelajaran dengan tidak maksimal. Masih ada guru yang memberikan pelajaran kepada siswanya dengan menyuruh ketua kelasnya yang mendiktekan mata pelajaran tersebut. Kemudian sang guru kembali ke kantor untuk berbicara. Biasanya guru tersebut ditegur oleh Kepala Madrasah, tetapi hanya diam saja. Sehingga siswa juga asal-asalan dalam belajar. Masalah lain adalah sarana belajar yang kurang mendukung, seperti perpustakaan yang kurang berfungsi dengan baik atau sarana belajar lainnya (Hj. Nurbaya, Wakil Kepala Madrasah, wawancara, 10 Maret 2013).

Faktor lain yang menyebabkan rendahnya prestasi siswa di Madrasah Tsanawiyah DDI Pacongang Pinrang menurut Guru Bimbingan dan Konseling adalah masih banyaknya siswa yang sering membolos pada saat jam pelajaran berlangsung. Ditambah dengan sarana yang kurang mendukung, banyaknya siswa yang membolos karena kompleks madrasah tidak dipagar, apalagi di sekitar lingkungan madrasah, terdapat kebun yang pohon rimbun sehingga memungkinkan siswa mudah membolos. Hal ini juga disebabkan kurangnya pengawasan dari guru piket atau wali kelas (Muh. Anwar, Guru BK, wawancara, 10 Maret 2013).

Menurut peneliti, penyebab rendahnya prestasi siswa Madrasah Tsanawiyah DDI Pacongang Pinrang bisa diatasi dengan menghilangkan atau setidaknya memini- 
malisir penyebab tersebut. Guru semestinya menyadari bahwa dirinya adalah pendidik, motivator dan teladan bagi siswanya. Pada saat pelajaran berlangsung, guru jangan meninggalkan ruangan kelas tanpa alasan yang jelas. Kalaupun mata pelajaran itu harus didiktekan, sebaiknya guru tersebut yang langsung mendiktekannya. Atau kalau diserahkan kepada salah seorang siswa untuk mendikte, guru jangan meninggalkan ruangan kelas. Ia harus mengawasi siswanya sampai pelajaran itu selesai didiktekan.

Demikian pula, masalah sarana pendukung atau sumber belajar harus dimaksimalkan fungsinya. Perpustakaan setahap demi setahap ditambah koleksi bukunya yang baru. Pihak madrasah dapat memberi syarat bahwa bagi siswa yang tamat, diwajibkan menyumbang minimal 1 judul buku. Mengenai siswa yang sering membolos, guru piket dan wali kelas dapat meningkatkan pengawasan yang dilakukan kepada siswanya. Bagi siswa yang sering membolos, diberikan sanksi yang setimpal yang mendidik. Atau dipanggil orangtuanya untuk menemukan solusi terbaik, demi peningkatan kualitas pendidikan di Madrasah Tsanawiyah DDI Pacongang Pinrang.

Adapun hambatan dalam peningkatan kualitas pendidikan yaitu kurangnya pemerataan pendidikan, rendahnya relevansi pendidikan dengan kebutuhan serta mahalnya biaya pendidikan merupakan tugas utama pemerintah, baik pemeritah pusat maupun pemerintah daerah. Untuk meningkatkan pemerataan pendidikan seharusnya pemerintah menanggung biaya minimun pendidikan, memberikan subsidi kepada sekolah/madrasah baik negeri maupun swasta. Sementara untuk meningkatkan relevansi pendidikan dengan kebutuhan kerja, pemerintah perlu melakukan pembenahan kurikulum pendidikan yang memberikan kemampuan dan keterampilan dasar minimum (minimum basic skills), menerapkan belajar tuntas (mastery learning) serta membangkitkan semangat kreatif dan mandiri bagi siswa.

\section{DAFTAR PUSTAKA:}

Arifin, M. (2000). Kapita Selekta Pendidikan (Islam dan Umum), Cet. IV; Jakarta: Bumi Aksara.

Good, C.V. (1973). Dictionary of Education, Third Edition. New York: McGraw-Hill: Book Company.

Hamalik, O. (2006). Pendidikan Guru Berdasarkan Pendekatan Kompetensi, Cet. Ke - 4; Jakarta: PT. Bumi Aksara.

http://ayieenfysalhabsyie.blogspot.com/2012/03/karakteristik-guruprofesional .html

http://makalahfrofesikependidikan.blogspot.com/2010/07/makalah-profesi-dan-profesional-guru.html.

Koontz, H. C. D., \& Heinz, W. (1984). Management, Eight Edition 1. Auckland McGraw-Hill International Book Company.

Kunandar. (2007). Guru Profesional Implementasi Kurikulum Tingkat Satuan Pendidikan (KTSP) dan Persiapan menghadapi Sertifikasi Guru, Cet. Ke-1, Jakarta : PT. Raja Grafindo Persada.

Made, A. W (2009). Strategi Pembelajaran Inovatif Kontemporer. Jakarta: Bumi Aksara.

Moleong, L. J. (1992). Metode Penelitian Kualitatif, Cet. III; Bandung: Remadja RosdaKarya.

Mujib, F. (2012). Super Power In Educating (Kegiatan Belajar Mengajar Yang Super Efektif)., Yogyakkarta: Diva Press.

Mujtahid. (2010). Pemberdayaan Komite Sekolah. (Online). http: Mujtahidkomunitaspendidik- 
an.blogspot.com/2010/05/pemberdayaan-komite-sekolah.html. diakses 07 Desember 2016.

Muzdalifah. (2008). Psikologi Pendidikan. Kudus: STAIN.

Nata, A. (2001). Pemikiran Para Tokoh Pendidikan Islam; Seri Kajian Fi/safat Pendidikan Islam, Edisi I; Cet. 11; Jakarta: PT. Raja Grafindo Persada.

Pidarta, M. (1988). Manajemen Pendidikan Indonesia, Cet. I; Jakarta: Bina Aksara.

Sagala, S. (2010). Konsep dan Makna Pembelajaran. Alfabeta: Bandung.

Sardiman. (2001). Interaksi dan Motivasi Belajar Mengajar. Jakarta: PT RajaGrafindo Persada.

Shihab, M. Q. (1994). Wawasan al-Quran. Bandung: Mizan.

Soetjipto \& Raflis, K. (2009). Profesi Keguruan. Jakarta: Rineka Cipta.

Sugiono. (1998). Metode Penelitian Administrasi, Edisi ke-5; Bandung: Alfabeta.

Tafsir, A. (2000). Ilmu Pendidikan Dalam Persfektif Islam, Cet. Ill; Jakarta: PT. Remaja Rosdakarya.

(2006). Undang-Undang Republik Indonesia No. 14 Tahun 2005 tentang Guru dan Dosen. Bandung: Citra Umbara. 